Article

\title{
Efficient Hydrolysis of Lignocellulose by Acidic Ionic Liquids under Low-Toxic Condition to Microorganisms
}

\author{
Kosuke Kuroda ${ }^{1, *}$, Ken Inoue ${ }^{1}$, Kyohei Miyamura ${ }^{1}$, Heri Satria ${ }^{1,2}$, Kenji Takada ${ }^{1}$, \\ Kazuaki Ninomiya ${ }^{3}$ and Kenji Takahashi ${ }^{1, *}$ \\ 1 Division of Natural System, Graduate School of Natural Science and Technology, Kanazawa University, \\ Kakuma-machi, Kanazawa 920-1192, Japan; kinoue0831@gmail.com (K.I.); \\ kyo0524@stu.kanazawa-u.ac.jp (K.M.); herisatria@stu.kanazawa-u.ac.jp (H.S.); \\ takadaken@se.kanazawa-u.ac.jp (K.T.) \\ 2 Department of Chemistry, Faculty of Mathematics and Natural Sciences, University of Lampung, \\ Jl. Soemantri Brojonegoro No.1, Bandar Lampung 35145, Indonesia \\ 3 Institute for Frontier Science Initiative, Kanazawa University, Kakuma-machi, Kanazawa 920-1192, Japan; \\ ninomiya@se.kanazawa-u.ac.jp \\ * Correspondence: kkuroda@staff.kanazawa-u.ac.jp (K.K.); ktkenji@staff.kanazawa-u.ac.jp (K.T.); \\ Tel.: +81-76-234-4828 (K.K. \& K.T.)
}

Academic Editors: Montserrat Gómez and Daniel Pla

Received: 10 March 2017; Accepted: 6 April 2017; Published: 7 April 2017

\begin{abstract}
Lignocellulose is known as a renewable resource, and acidic ionic liquids have been highlighted as efficient catalysts for hydrolysis of cellulose. To achieve successive hydrolysis and fermentation, efficient hydrolysis with sufficiently diluted acidic ionic liquids is necessary because acidic ionic liquids are toxic to fermentative microorganisms. Escherichia coli was confirmed to grow in $0.05 \mathrm{M}$ dilute acidic ionic liquid-1-(1-butylsulfonic)-3-methylimidazolium hydrogen sulfate ([Sbmim] $\left[\mathrm{HSO}_{4}\right]$ ) —although the growth was suppressed in more concentrated solutions. Therefore, we applied the $0.05 \mathrm{M}$ [Sbmim] $\left[\mathrm{HSO}_{4}\right]$ solution to hydrolysis of bagasse, leading to a glucose yield of $48 \%$ at $190{ }^{\circ} \mathrm{C}$. This value is greater than that obtained with a concentrated $[\mathrm{Sbmim}]\left[\mathrm{HSO}_{4}\right]$ solution, which is not suitable for the growth of Escherichia coli (yield: $40 \%$ in a $1.0 \mathrm{M}$ solution). Efficient hydrolysis with acidic ionic liquids under low-toxic condition was achieved.
\end{abstract}

Keywords: acidic ionic liquid; hydrolysis; biomass

\section{Introduction}

Carbohydrates account for $75 \%$ of annual renewable biomass. Among the various types of carbohydrates, cellulose is the most attractive because it is inedible and inexpensive; furthermore, it can be obtained on a large scale from biomass (ca. $45 \%$ of biomass) [1]. Recently, the efficient conversion of cellulose to glucose for the production of ethanol and critical building blocks such as succinic acid and gluconic acid via fermentation has been extensively studied [1,2]. Acidic or enzymatic hydrolysis has been used to obtain glucose from cellulose. Hydrolysis using dilute acid is known to be a simple, cost-effective method; however, it gives low sugar yields and requires a long reaction time [3]. To improve hydrolysis yield, efficient catalysts are strongly requested.

Recently, certain ionic liquids (ILs) have been applied in the processing of cellulose [4-9]. Because of their remarkable capacity to delignify and solubilize cellulose, the ILs are often used for pretreating lignocellulosic biomass before hydrolysis [10-15]. On the other hand, Davis et al. reported acidic ILs having an acidic group such as a sulfo group in their cationic and/or anionic structures [16-20], and the acidic ILs exhibit higher catalytic activity in cellulose hydrolysis compared to sulfuric acid [21]. 
Furthermore, it has been reported that microwave heating accelerates hydrolysis of cellulose in $1.0 \mathrm{M}$ acidic IL, 1-(1-butylsulfonic)-3-methylimidazolium hydrogen sulfate ([Sbmim][HSO $\left.\mathrm{H}_{4}\right]$; Figure 1) [22], because the combination of ILs and microwave is known to exert synergistic effects on several reactions [23-25]. In the literature, the glucose yield has increased from a few percent after $30 \mathrm{~min}$ to $40 \%$ after $12 \mathrm{~min}$ at $160{ }^{\circ} \mathrm{C}$ when using microwave irradiation.<smiles>Cn1cc[n+](CCC[Sb](=O)(=O)O[Na])c1</smiles>

Figure 1. The structure of $[\mathrm{Sbmim}]\left[\mathrm{HSO}_{4}\right]$.

However, the concentrated $\left.\left[\mathrm{Sbmim}_{[}\right] \mathrm{HSO}_{4}\right]$ solution $(1.0 \mathrm{M}$ in the previous literature) is not suitable for the successive microbial utilization, e.g., the fermentation of glucose to ethanol or other valuable building blocks, because the concentrated $[\mathrm{Sbmim}]\left[\mathrm{HSO}_{4}\right]$ solution is lethal to microorganisms due to its acidity and the intrinsic toxicity of ILs [26-29]. Especially, the intrinsic toxicity of IL cannot be reduced unlike the toxicity by acidity (reduced by neutralization): sufficiently dilute solution has to be used. Since there is no report satisfying both conditions-microbial viability and a high yield of sugars-with acidic ILs, in this study, we attempted the efficient hydrolysis of cellulose with a $\left[\mathrm{Sbmim}_{[}\left[\mathrm{HSO}_{4}\right]\right.$ solution that is sufficiently dilute to be undisruptive to the growth of Escherichia coli (E. coli).

\section{Results and Discussion}

\subsection{Effect of [Sbmim $]\left[\mathrm{HSO}_{4}\right]$ on E. coli Growth}

First of all, the toxicity of [Sbmim] $\left[\mathrm{HSO}_{4}\right]$ was investigated because the toxicity of acidic ILs has not been studied. Figure 2 shows the time course of the optical density at $600 \mathrm{~nm}\left(\mathrm{OD}_{600}\right)$ of the $\left[\mathrm{Sbmim}_{[}\left[\mathrm{HSO}_{4}\right] /\right.$ medium mixed solutions during culturing E. coli. $\mathrm{OD}_{600}$ is a conventional indicator of the E. coli concentration. At [Sbmim] $\left[\mathrm{HSO}_{4}\right]$ concentrations of 1.00 and $0.50 \mathrm{M}$, the $\mathrm{OD}_{600}$ after $24 \mathrm{~h}$ was 0.1 and 0.3 , respectively, indicating severe growth inhibition. In contrast, E. coli grew and the $\mathrm{OD}_{600}$ increased to 2.0 within $24 \mathrm{~h}$ in a $0.05 \mathrm{M}$ [Sbmim] $\left[\mathrm{HSO}_{4}\right]$ solution. Although E. coli thrived more in a pure medium without [Sbmim] $\left[\mathrm{HSO}_{4}\right]$, resulting in an $\mathrm{OD}_{600}$ of 5.0 within $24 \mathrm{~h}$ (Figure S1, see Supplementary Materials), it is confirmed that $E$. coli surely grew in the $0.05 \mathrm{M}$ solution with almost half the growth ratio of that in the pure medium. Therefore, we decided to apply the $0.05 \mathrm{M}$ solution to the hydrolysis of cellulose.

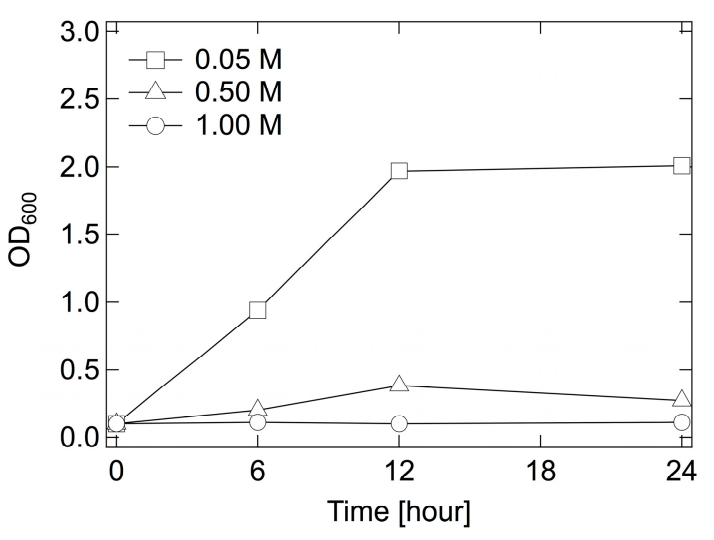

Figure 2. Time course of $\mathrm{OD}_{600}$ of $[\mathrm{Sbmim}]\left[\mathrm{HSO}_{4}\right] /$ medium mixed solutions during E. coli culturing.

As mentioned above, [Sbmim] $\left[\mathrm{HSO}_{4}\right]$ inhibited the growth of E. coli because of the IL structure itself and/or the acidity. To investigate the mechanism of toxicity, the same experiments using $\mathrm{H}_{2} \mathrm{SO}_{4}$ 
and 1-ethyl-3-methylimidazolium acetate, an IL that does not contain any acidic part, were also performed. All three compounds, [Sbmim] $\left[\mathrm{HSO}_{4}\right]$, 1-ethyl-3-methylimidazolium acetate, and $\mathrm{H}_{2} \mathrm{SO}_{4}$, exhibited a similar inhibitory effect on E. coli growth (Figures S2 and S3, see Supplementary Materials). Hence, the toxicity of $\left.\left[\mathrm{Sbmim}_{[}\right] \mathrm{HSO}_{4}\right]$ may be attributed to both the IL structure and the acidity.

\subsection{Hydrolysis of Bagasse in a $0.05 \mathrm{M}\left[\mathrm{Sbmim}_{[}\left[\mathrm{HSO}_{4}\right]\right.$ Solution}

Figure 3 shows the glucose yield during hydrolysis using $0.05 \mathrm{M}[\mathrm{Sbmim}]\left[\mathrm{HSO}_{4}\right]$ solutions at $160{ }^{\circ} \mathrm{C}$. The glucose yield gradually increased in the $0.05 \mathrm{M}$ solution, and reached a maximum of $37 \%$. In a concentrated solution $(1.00 \mathrm{M})$, the glucose yield reached a maximum of $40 \%$, and then decreased. It is confirmed that the $0.05 \mathrm{M}$ solution can hydrolyze bagasse with a comparable yield to that of the $1.00 \mathrm{M}$ solution.

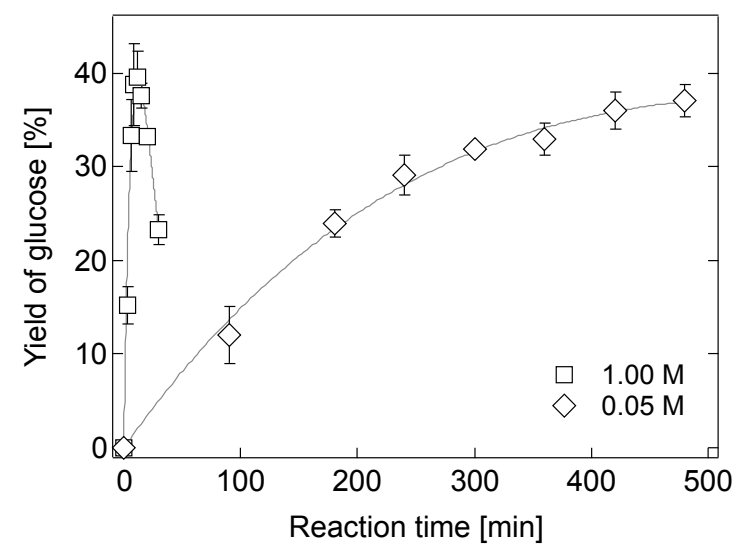

Figure 3. Time courses of glucose yields during bagasse hydrolysis in 1.00 and $0.05 \mathrm{M}$ [Sbmim] $\left[\mathrm{HSO}_{4}\right]$ solutions at $160^{\circ} \mathrm{C}$.

The reactions in the samples proceeded with different rates. Peak yields in 1.00 and $0.05 \mathrm{M}$ solutions were attained after approximately 12 and $500 \mathrm{~min}$, respectively. The [Sbmim] $\left[\mathrm{HSO}_{4}\right]$ concentration was confirmed to affect the reaction rate, and the low reaction rate at $0.05 \mathrm{M}$ is expected to be improved by elevating the reaction temperature.

Figure 4 shows the time courses of the glucose yields during bagasse hydrolysis in the $0.05 \mathrm{M}$ [Sbmim] $\left[\mathrm{HSO}_{4}\right]$ solutions at 190 and $200{ }^{\circ} \mathrm{C}$. The reaction rate improved in both cases, compared to that at $160{ }^{\circ} \mathrm{C}$ (see Figure 3): peak yields at 190 and $200{ }^{\circ} \mathrm{C}$ were obtained after 35 and $12 \mathrm{~min}$, respectively. The glucose yield was also improved by increasing temperature: the peak yields at 190 and $200{ }^{\circ} \mathrm{C}$ were 48 and $47 \%$, respectively. We were able to reduce the [Sbmim] $\left[\mathrm{HSO}_{4}\right]$ concentration to decrease the toxicity and improve the glucose yield, compared to the hydrolysis using the $1.00 \mathrm{M}$ solution. In addition, the glucose yield at $180^{\circ} \mathrm{C}$ was $43 \%$ within $40 \mathrm{~min}$ (Figure S4; see Supplementary Materials). Reaction temperatures of greater than $190^{\circ} \mathrm{C}$ are favorable for attaining a high glucose yield.

To investigate the reason behind the improvement of the glucose yield, we estimated $k_{1}$ and $k_{2}$ (based on Equations (1) and (2), see experimental section; results are shown in Table 1). The $k_{1}$ and $k_{2}$ depended strongly on both the $[\mathrm{Sbmim}]\left[\mathrm{HSO}_{4}\right]$ concentration and the temperature. For example, $k_{1}$ and $k_{2}$ obtained with the $0.05 \mathrm{M}$ [Sbmim] $\left[\mathrm{HSO}_{4}\right]$ solution at $190{ }^{\circ} \mathrm{C}$ were $3.4 \times 10^{-2}$ and $2.1 \times 10^{-2} \mathrm{~min}^{-1}$ (Entry 3), whereas those obtained with a $1.00 \mathrm{M}$ solution at $160^{\circ} \mathrm{C}$ were $8.4 \times 10^{-2}$ and $7.5 \times 10^{-2} \mathrm{~min}^{-1}$ (Entry 5, the optimum condition in $1.00 \mathrm{M}$ [Sbmim][HSO $\left.{ }_{4}\right]$ solution). 


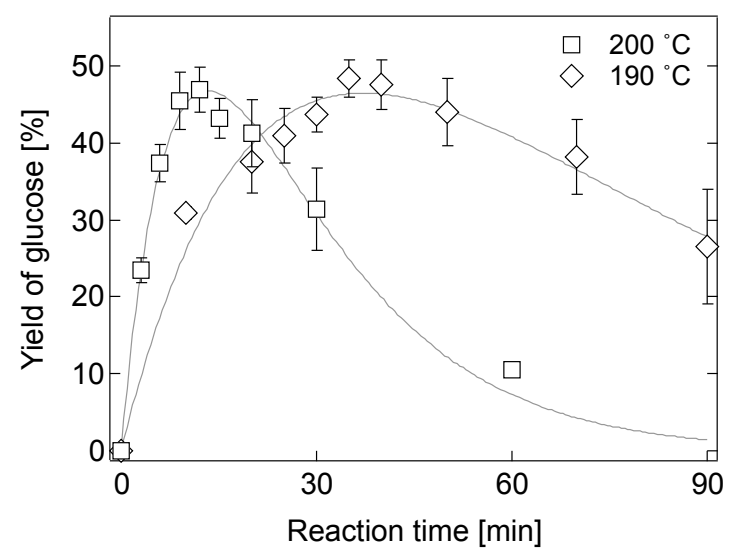

Figure 4. Time courses of glucose yields during the hydrolysis of bagasse in the $0.05 \mathrm{M}$ [Sbmim] $\left[\mathrm{HSO}_{4}\right]$ solution at 190 and $200{ }^{\circ} \mathrm{C}$.

Table 1. $k_{1}, k_{2}, k_{1} / k_{2}$, and glucose yield of the samples hydrolyzed in [Sbmim][HSO 4$]$ solutions.

\begin{tabular}{ccccccc}
\hline Entry & Temperature $\left({ }^{\circ} \mathbf{C}\right)$ & Concentration $(\mathbf{M})$ & $\boldsymbol{k}_{\mathbf{1}}\left(\mathbf{m i n}^{-\mathbf{1}}\right)$ & $\boldsymbol{k}_{\mathbf{2}}\left(\mathbf{m i n}^{-\mathbf{1}}\right)$ & $\boldsymbol{k}_{\mathbf{1}} / \boldsymbol{k}_{\mathbf{2}}$ & Yield (\%) \\
\hline 1 & 160 & 0.05 & $1.8 \times 10^{-3}$ & $0.17 \times 10^{-2}$ & 1.0 & 37 \\
2 & 180 & 0.05 & $2.3 \times 10^{-2}$ & $1.7 \times 10^{-2}$ & 1.4 & 43 \\
3 & 190 & 0.05 & $3.4 \times 10^{-2}$ & $2.1 \times 10^{-2}$ & 1.7 & 48 \\
4 & 200 & 0.05 & $9.6 \times 10^{-2}$ & $5.7 \times 10^{-2}$ & 1.7 & 47 \\
5 & 160 & 1.00 & $8.4 \times 10^{-2}$ & $7.5 \times 10^{-2}$ & 1.1 & 40 \\
6 & 190 & 0.10 & $9.8 \times 10^{-2}$ & $5.9 \times 10^{-2}$ & 1.7 & 50 \\
\hline
\end{tabular}

A large $k_{1}$ and small $k_{2}$ are necessary for attaining a high glucose yield; hence, we investigated the ratio of $k_{1}$ to $k_{2}\left(k_{1} / k_{2}\right)$. Using $0.05 \mathrm{M}$ [Sbmim] [HSO ${ }_{4}$ ] solutions at $160,180,190$, and $200{ }^{\circ} \mathrm{C}$, we obtained $k_{1} / k_{2}$ ratios of $1.0,1.4,1.7$, and 1.7 , which correspond to glucose yields of $37 \%, 43 \%, 48 \%$, and $47 \%$, respectively (Entries 1-4; Table 1). These results indicate that a high temperature results in a high $k_{1} / k_{2}$ ratio and thus a high glucose yield. As compared with temperature, the [Sbmim] $\left[\mathrm{HSO}_{4}\right]$ concentration exerts a smaller effect on $k_{1} / k_{2}$. As shown in Entries 1 and $5, k_{1} / k_{2}$ ratios obtained with 0.05 and $1.00 \mathrm{M}$ solutions at $160{ }^{\circ} \mathrm{C}$ were 1.0 and 1.1 , respectively; the $k_{1} / k_{2}$ ratios obtained with 0.05 and $0.10 \mathrm{M}$ solutions at $190{ }^{\circ} \mathrm{C}$ were both 1.7 (Entries 3 and 6). From these results, the improvement in glucose yield in the $0.05 \mathrm{M}$ solution may be attributed to the high $k_{1} / k_{2}$ ratio due to high temperature.

The activation energy for hydrolysis of bagasse cellulose in the $0.05 \mathrm{M}[\mathrm{Sbmim}]\left[\mathrm{HSO}_{4}\right]$ solution was $167 \mathrm{~kJ} / \mathrm{mol}$; this value is less than that for cellulose hydrolysis using a diluted $\mathrm{H}_{2} \mathrm{SO}_{4}$ solution (180 kJ/mol for Douglas fir [30] and $190 \mathrm{~kJ} / \mathrm{mol}$ for corn stover [31]). For glucose decomposition in the $0.05 \mathrm{M}$ [Sbmim] $\left[\mathrm{HSO}_{4}\right.$ ] solution, the activation energy was $144 \mathrm{~kJ} / \mathrm{mol}$; this value is greater than that obtained with a dilute $\mathrm{H}_{2} \mathrm{SO}_{4}$ solution $(138 \mathrm{~kJ} / \mathrm{mol}$ for Douglas fir [30] and $137 \mathrm{~kJ} / \mathrm{mol}$ for corn stover [31]). The differences of the activation energies support that the present method is favorable to an increase in the yield.

\subsection{Hydrolysis of Various Biomass}

To confirm the utility of the present method, we hydrolyzed hardwood and softwood samples, eucalyptus and Japanese cedar, respectively, in addition to bagasse. Because of their abundance and their suitability as biomass for glucose production, these materials have attracted significant interest. Figure 5 shows the time courses of the glucose yields during the hydrolysis of bagasse, eucalyptus, and Japanese cedar in the $0.05 \mathrm{M}[\mathrm{Sbmim}]\left[\mathrm{HSO}_{4}\right]$ solutions at $190{ }^{\circ} \mathrm{C}$. As mentioned above, bagasse hydrolysis had a peak yield of $48 \%$ at $35 \mathrm{~min}$. With eucalyptus and Japanese cedar, glucose yields were $41 \%$ after $25 \mathrm{~min}$ and $45 \%$ after $30 \mathrm{~min}$, respectively. Because lower glucose yields in $1.00 \mathrm{M}$ 
[Sbmim] $\left[\mathrm{HSO}_{4}\right]$ solutions at $160{ }^{\circ} \mathrm{C}$ were obtained (37\% for eucalyptus and $30 \%$ for Japanese cedar), the diluted $\left[\mathrm{Sbmim}_{[}\left[\mathrm{HSO}_{4}\right]\right.$ solution was effective for the hydrolysis of various biomass sources.

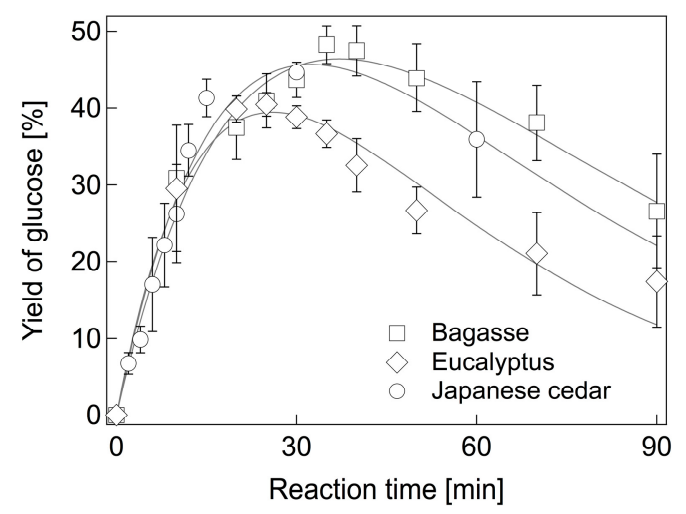

Figure 5. Time courses of glucose yields during the hydrolysis of bagasse, eucalyptus, and Japanese cedar in the $0.05 \mathrm{M}\left[\mathrm{Sbmim}_{[}\left[\mathrm{HSO}_{4}\right]\right.$ solutions at $190{ }^{\circ} \mathrm{C}$.

Figure 5 also shows difference in the duration for which the maximum yield was achieved $\left(t_{\max }\right)$ and the maximum yields $\left(Y_{\max }\right)$, depending on the biomass sources. To investigate the reason behind these different values, we measured the crystallinity of biomass. The crystallinity was determined by Fourier transform infrared (FTIR) spectroscopy by calculating the ratio of absorbance at 1437 and $899 \mathrm{~cm}^{-1}$, as reported by $\mathrm{O}^{\prime}$ Connor et al. [32]. The ratio of absorbance was 0.60 (bagasse), 0.87 (Eucalyptus), and 0.67 (Japanese cedar). Figure 6 shows the relation between the crystallinity of the cellulose present in biomass and $t_{\max }$ and $Y_{\max }$. As the crystallinity decreased, $t_{\max }$ and $Y_{\max }$ increased, indicating that the crystallinity of cellulose in biomass is confirmed to be a factor in resisting hydrolysis. It also indicates that a higher glucose yield is expected if pretreatments such as ball milling are applied.

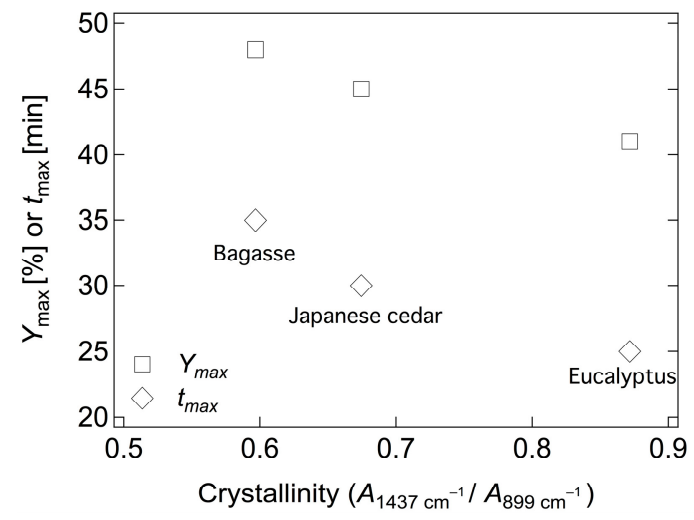

Figure 6. Relationship between the crystallinity of biomass and $Y_{\max }$ (square) and $t_{\max }$ (diamond).

FTIR measurements may also enable the prediction of $t_{\max }$ and $Y_{\max }$. The prediction of $t_{\max }$ is particularly useful because excessively short and long reaction times result in a low yield.

\subsection{Effect of Biomass Loading on Hydrolysis}

To efficiently utilize biomass, high loading is important. Hence, the loading of bagasse was increased from 20 to $100 \mathrm{~g} / \mathrm{L}$. Figure 7 shows the time courses of glucose concentrations during hydrolysis with 20 or $100 \mathrm{~g} / \mathrm{L}$ bagasse using $0.05 \mathrm{M}$ [Sbmim] $\left[\mathrm{HSO}_{4}\right]$ solutions at $190{ }^{\circ} \mathrm{C}$. Even at $100 \mathrm{~g} / \mathrm{L}$ loading, the glucose concentration increased within approximately $30 \mathrm{~min}$, suggesting that 
hydrolysis proceeded despite the absorption of a major part of the $[\mathrm{Sbmim}]\left[\mathrm{HSO}_{4}\right]$ solution by the bagasse particles (Table S1 shows photographs of solutions). With the 20 and $100 \mathrm{~g} / \mathrm{L}$ solutions, the peak glucose concentrations were 4.4 and $15.2 \mathrm{~g} / \mathrm{L}$, respectively, corresponding to a 3.5-fold increase in concentration. It is noted that the $100 \mathrm{~g} / \mathrm{L}$ solution produced a yield of $33 \%$, and the value was less than that obtained with the $20 \mathrm{~g} / \mathrm{L}$ solution (48\%) (Figure S5). In addition, the $t_{\max }$ for both the 20 and $100 \mathrm{~g} / \mathrm{L}$ solutions was around $30 \mathrm{~min}$, indicating that the present method can process a high loading of biomass within this period.

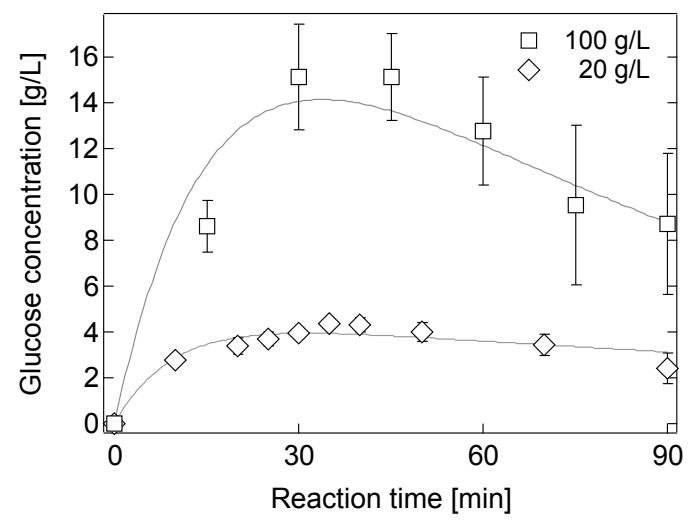

Figure 7. Time courses of glucose concentrations during hydrolysis of 20 and $100 \mathrm{~g} / \mathrm{L}$ bagasse solutions in the $0.05 \mathrm{M}\left[\mathrm{Sbmim}_{[}\left[\mathrm{HSO}_{4}\right]\right.$ solutions at $190{ }^{\circ} \mathrm{C}$.

\section{Materials and Methods}

\subsection{Materials}

Bagasse, eucalyptus, and Japanese cedar powder (particle diameter of approximately $3 \mathrm{~mm}$ ) were purchased from Sanwa Ceruciron (Yokkaichi, Japan). First, the biomass powder was ground in a mill and then sieved to form a powder with a particle diameter of 250-500 $\mu \mathrm{m}$. The cellulose content of the original lignocellulosic biomass was determined according to a reported method [33]. [Sbmim][ $\mathrm{HSO}_{4}$ ] (Solvionic, Toulouse, France) was used as received. Escherichia coli (E. coli KO11, ATCC 55124) was purchased from Summit Pharmaceuticals International Corporation (Tokyo, Japan).

\subsection{The Effect of [Sbmim] $\left[\mathrm{HSO}_{4}\right]$ on E. coli Growth}

E. coli was aerobically precultured at $37^{\circ} \mathrm{C}$ in a test tube containing $5 \mathrm{~mL}$ of medium $(5 \mathrm{~g} / \mathrm{L}$ yeast extract, $5 \mathrm{~g} / \mathrm{L} \mathrm{NaCl}$, and $10 \mathrm{~g} / \mathrm{L}$ tryptone; Nacalai Tesque, Kyoto, Japan). The precultured broth was transferred to $2 \mathrm{~mL}$ of the medium containing [Sbmim] $\left[\mathrm{HSO}_{4}\right]$. The initial $\mathrm{OD}_{600}$ was set at 0.1 . Each was incubated at $37^{\circ} \mathrm{C}$ for $24 \mathrm{~h}$ on a reciprocal shaker at $160 \mathrm{rpm}$. The culture broth was then sampled at 6,12 , and $24 \mathrm{~h}$, and the $\mathrm{OD}_{600}$ was measured.

\subsection{Microwave-Assisted Hydrolysis of Biomass in an Aqueous [Sbmim] $\left[\mathrm{HSO}_{4}\right]$ Solution}

Biomass $(0.30 \mathrm{~g})$ was suspended in $[\mathrm{Sbmim}]\left[\mathrm{HSO}_{4}\right]$ solutions $(15 \mathrm{~mL})$, and the resulting mixture was then transferred to a $100 \mathrm{~mL}$ vessel (HPR-1000/10; Milestone s.r.l., Sorisole, Italy). The vessel was then heated in a microwave synthesizer (StartSYNTH; Milestone s.r.l.).

For sampling, the vessel was removed from the microwave system and immediately cooled in an ice bath to quench the reaction. An aliquot of the sample solution $(500 \mu \mathrm{L})$ was centrifuged at $15,000 \mathrm{rpm}$ for $2 \mathrm{~min}$ to precipitate the solids. The supernatant was filtered and then subjected to glucose analysis as described below. 


\subsection{Analysis of Glucose Yield}

We evaluated the efficacy of hydrolysis by the glucose yield because cellulose is considerably difficult to hydrolyze due to its high crystallinity, as compared with hemicellulose. The glucose concentration in the hydrolyzate was determined using a high performance liquid chromatography equipped with a refractive index detector (Shimadzu Co., Kyoto, Japan). A sugar KS-801 column (Showa Denko K.K., Tokyo, Japan) was used in tandem with a sugar KS-G guard column (Showa Denko K.K.). The volume of the injected sample was $10 \mu \mathrm{L}$. The column was operated at $80^{\circ} \mathrm{C}$, and ultrapure water was used as the mobile phase (a flow rate of $1.0 \mathrm{~mL} / \mathrm{min}$ ).

\subsection{Determination of Reaction Rate Constants}

During acid hydrolysis, cellulose is hydrolyzed to glucose, which is then decomposed. Hydrolysis and decomposition of cellulose may be described by the pseudo-homogeneous consecutive first-order reactions [30]:

$$
\text { Cellulose } \stackrel{k_{1}}{\rightarrow} \text { Glucose } \stackrel{k_{2}}{\rightarrow} \text { Decomposition product }
$$

where $k_{1}$ and $k_{2}$ represent the rate constants for the hydrolysis of cellulose to glucose and for the decomposition of glucose, respectively. The glucose concentration, $C_{\text {glucose }}$, is expressed as follows:

$$
C_{\text {glucose }}=a \frac{k_{1}}{k_{2}-k_{1}}\left[e^{-k_{1} t}-e^{-k_{2} t}\right]
$$

where the initial cellulose concentration is expressed as glucose equivalents. The reaction rate constants, $k_{1}$ and $k_{2}$, were determined by fitting Equation (2) to the experimental data according to the nonlinear least-squares method by using Igor Pro software (WaveMetrics, Inc., Portland, OR, USA).

\section{Conclusions}

In this study, cellulose present in lignocellulosic biomass was hydrolyzed by using a $0.05 \mathrm{M}$ $[\mathrm{Sbmim}]\left[\mathrm{HSO}_{4}\right]$ solution under microwave heating. The $0.05 \mathrm{M}\left[\mathrm{Sbmim}^{2}\right]\left[\mathrm{HSO}_{4}\right]$ solution was sufficiently low to allow for the growth of E. coli. The glucose yield during hydrolysis in the $0.05 \mathrm{M}$ solution $(48 \%)$ was higher than that obtained in the $1.00 \mathrm{M}$ [Sbmim] $\left[\mathrm{HSO}_{4}\right]$ solution $(40 \%)$, under the optimized conditions. The higher yield was attributed to a high $k_{1} / k_{2}$ ratio due to the maximum temperatures applicable to the $1.00 \mathrm{M}$ and $0.05 \mathrm{M}$ solutions, namely $160^{\circ} \mathrm{C}$ and $190{ }^{\circ} \mathrm{C}$, respectively. The dilute $[\mathrm{Sbmim}]\left[\mathrm{HSO}_{4}\right]$ solution was also applicable to softwood and hardwood, which is more recalcitrant than herbaceous biomass. The yield at $190{ }^{\circ} \mathrm{C}$ was $41 \%$ for eucalyptus and $45 \%$ for Japanese cedar.

Supplementary Materials: The following are available online at www.mdpi.com/2073-4344/7/4/108/s1, Figure S1: Time courses of $\mathrm{OD}_{600}$ of a pure medium during culturing E. coli, Figure S2: time courses of $\mathrm{OD}_{600}$ of 1-ethyl-3-methylimidazolium acetate/medium mixed solutions during culturing E. coli, Figure S3: Time courses of $\mathrm{OD}_{600}$ of $\mathrm{H}_{2} \mathrm{SO}_{4}$ / medium mixed solutions during culturing E. coli, Figure S4: time course of glucose yield during bagasse hydrolysis in the $0.05 \mathrm{M}\left[\mathrm{Sbmim}_{[}\left[\mathrm{HSO}_{4}\right]\right.$ solution at $180{ }^{\circ} \mathrm{C}$, Figure S5: Time courses of glucose yields during hydrolysis of 20 and $100 \mathrm{~g} / \mathrm{L}$ bagasse solutions in the $0.05 \mathrm{M}$ [Sbmim] $\left[\mathrm{HSO}_{4}\right]$ solutions at $190{ }^{\circ} \mathrm{C}$, Table S1: photographs of the $[\mathrm{Sbmim}]\left[\mathrm{HSO}_{4}\right]$ solutions with different bagasse loadings.

Acknowledgments: This research was supported in part by the Center of Innovation (COI) program "Construction of next-generation infrastructure using innovative materials-Realization of a safe and secure society that can coexist with the Earth for centuries," the Advanced Low Carbon Technology Research and Development Program (ALCA) (No. 2100040 to K.T.), and the Cross-Ministerial Strategic Innovation Promotion Program (SIP) by JST. This study was also partly supported by a Grant-in-Aid for Scientific Research from the Japan Society for the Promotion of Science.

Author Contributions: K.K., K. Takada, K.N., and K. Takahashi conceived and designed the experiments and thoroughly discussed the results and hypotheses; K.I., K.M. and H.S. performed the experiments; K.K. wrote the paper.

Conflicts of Interest: The authors declare no conflict of interest. 


\section{References}

1. Song, J.; Fan, H.; Ma, J.; Han, B. Conversion of Glucose and Cellulose into Value-Added Products in Water and Ionic Liquids. Green Chem. 2013, 15, 2619-2635. [CrossRef]

2. Werpy, T.; Petersen, G. Top Value Added Chemicals From Biomass Volume I-Results of Screening for Potential Candidates from Sugars and Synthesis Gas; U.S. Department of Energy: Oak Ridge, TN, USA, 2004.

3. Amarasekara, A.S.; Wiredu, B. Aryl Sulfonic Acid Catalyzed Hydrolysis of Cellulose in Water. Appl. Catal. A Gen. 2012, 417-418, 259-262. [CrossRef]

4. Swatloski, R.P.; Spear, S.K.; Holbrey, J.D.; Rogers, R.D. Dissolution of Cellose with Ionic Liquids. J. Am. Chem. Soc. 2002, 124, 4974-4975. [CrossRef] [PubMed]

5. Fukaya, Y.; Hayashi, K.; Wada, M.; Ohno, H. Cellulose Dissolution with Polar Ionic Liquids under Mild Conditions: Required Factors for Anions. Green Chem. 2008, 10, 44-46. [CrossRef]

6. Fukaya, Y.; Sugimoto, A.; Ohno, H. Superior Solubility of Polysaccharides in Low Viscosity, Polar, and Halogen-Free 1,3-Dialkylimidazolium Formates. Biomacromolecules 2006, 7, 3295-3297. [CrossRef] [PubMed]

7. Brandt, A.; Gräsvik, J.; Hallett, J.P.; Welton, T. Deconstruction of Lignocellulosic Biomass with Ionic Liquids. Green Chem. 2013, 15, 550-583. [CrossRef]

8. Armand, M.; Endres, F.; MacFarlane, D.R.; Ohno, H.; Scrosati, B. Ionic-Liquid Materials for the Electrochemical Challenges of the Future. Nat. Mater. 2009, 8, 621-629. [CrossRef] [PubMed]

9. Kilpeläinen, I.; Xie, H.; King, A.; Granstrom, M.; Heikkinen, S.; Argyropoulos, D.S. Dissolution of Wood in Ionic Liquids. J. Agric. Food Chem. 2007, 55, 9142-9148. [CrossRef] [PubMed]

10. Ninomiya, K.; Kamide, K.; Takahashi, K.; Shimizu, N. Enhanced Enzymatic Saccharification of Kenaf Powder after Ultrasonic Pretreatment in Ionic Liquids at Room Temperature. Bioresour. Technol. 2012, 103, 259-265. [CrossRef] [PubMed]

11. Ninomiya, K.; Ohta, A.; Omote, S.; Ogino, C.; Takahashi, K.; Shimizu, N. Combined Use of Completely Bio-Derived Cholinium Ionic Liquids and Ultrasound Irradiation for the Pretreatment of Lignocellulosic Material to Enhance Enzymatic Saccharification. Chem. Eng. J. 2013, 215, 811-818. [CrossRef]

12. Ninomiya, K.; Kohori, A.; Tatsumi, M.; Osawa, K.; Endo, T.; Kakuchi, R.; Ogino, C.; Shimizu, N.; Takahashi, K. Ionic Liquid/Ultrasound Pretreatment and in Situ Enzymatic Saccharification of Bagasse Using Biocompatible Cholinium Ionic Liquid. Bioresour. Technol. 2015, 176, 169-174. [CrossRef] [PubMed]

13. Dadi, A.P.; Varanasi, S.; Schall, C.A. Enhancement of Cellulose Saccharification Kinetics Using an Ionic Liquid Pretreatment Step. Biotechnol. Bioeng. 2006, 95, 904-910. [CrossRef] [PubMed]

14. Kamiya, N.; Matsushita, Y.; Hanaki, M.; Nakashima, K.; Narita, M.; Goto, M.; Takahashi, H. Enzymatic in Situ Saccharification of Cellulose in Aqueous-Ionic Liquid Media. Biotechnol. Lett. 2008, 30, 1037-1040. [CrossRef] [PubMed]

15. Shi, J.; Balamurugan, K.; Parthasarathi, R.; Sathitsuksanoh, N.; Zhang, S.; Stavila, V.; Subramanian, V.; Simmons, B.A.; Singh, S. Understanding the Role of Water During Ionic Liquid Pretreatment of Lignocellulose: Co-Solvent or Anti-Solvent? Green Chem. 2014, 16, 3830-3840. [CrossRef]

16. Cole, A.C.; Jensen, J.L.; Ntai, I.; Tran, K.L.T.; Weaver, K.J.; Forbes, D.C.; Davis, J.H. Novel Brønsted Acidic Ionic Liquids and Their Use as Dual Solvent-Catalysts. J. Am. Chem. Soc. 2002, 124, 5962-5963. [CrossRef] [PubMed]

17. Zhao, G.; Jiang, T.; Gao, H.; Han, B.; Huang, J.; Sun, D. Mannich Reaction Using Acidic Ionic Liquids as Catalysts and Solventselectronic. Green Chem. 2004, 6, 75-77. [CrossRef]

18. Joseph, T.; Sahoo, S.; Halligudi, S.B. Brönsted Acidic Ionic Liquids: A Green, Efficient and Reusable Catalyst System and Reaction Medium for Fischer Esterification. J. Mol. Catal. A Chem. 2005, 234, 107-110. [CrossRef]

19. Han, X.-X.; Du, H.; Hung, C.-T.; Liu, L.-L.; Wu, P.-H.; Ren, D.-H.; Huang, S.-J.; Liu, S.-B. Syntheses of Novel Halogen-Free Brønsted-Lewis Acidic Ionic Liquid Catalysts and Their Applications for Synthesis of Methyl Caprylate. Green Chem. 2015, 17, 499-508. [CrossRef]

20. Kuroda, K.; Miyamura, K.; Satria, H.; Takada, K.; Ninomiya, K.; Takahashi, K. Hydrolysis of Cellulose Using an Acidic and Hydrophobic Ionic Liquid and Subsequent Separation of Glucose Aqueous Solution from the Ionic Liquid and 5-(Hydroxymethyl)Furfural. ACS Sustain. Chem. Eng. 2016, 4, 3352-3356. [CrossRef]

21. Amarasekara, A.S.; Wiredu, B. Degradation of Cellulose in Dilute Aqueous Solutions of Acidic Ionic Liquid 1-(1-Propylsulfonic)-3-Methylimidazolium Chloride, and P-Toluenesulfonic Acid at Moderate Temperatures and Pressures. Ind. Eng. Chem. Res. 2011, 50, 12276-12280. [CrossRef] 
22. Kuroda, K.; Inoue, K.; Miyamura, K.; Takada, K.; Ninomiya, K.; Takahashi, K. Enhanced Hydrolysis of Lignocellulosic Biomass Assisted by a Combination of Acidic Ionic Liquids and Microwave Heating. J. Chem. Eng. Jpn. 2016, 49, 809-813. [CrossRef]

23. Martínez-Palou, R. Ionic Liquid and Microwave-Assisted Organic Synthesis: A “Green” and Synergic Couple. J. Mex. Chem. Soc. 2007, 51, 252-264.

24. Hoffmann, J.; Nüchter, M.; Ondruschka, B.; Wasserscheid, P. Ionic Liquids and Their Heating Behaviour during Microwave Irradiation-A State of the Art Report and Challenge to Assessment. Green Chem. 2003, 5, 296-299. [CrossRef]

25. Guerrero-Sanchez, C.; Hoogenboom, R.; Schubert, U.S. Fast and “Green” Living Cationic Ring Opening Polymerization of 2-Ethyl-2-Oxazoline in Ionic Liquids under Microwave Irradiation. Chem. Commun. 2006, 36, 3797-3799. [CrossRef] [PubMed]

26. Zhao, D.; Liao, Y.; Zhang, Z. Toxicity of Ionic Liquids. CLEAN Soil Air Water 2007, 35, 42-48. [CrossRef]

27. Lim, G.S.; Zidar, J.; Cheong, D.W.; Jaenicke, S.; Klähn, M. Impact of Ionic Liquids in Aqueous Solution on Bacterial Plasma Membranes Studied with Molecular Dynamics Simulations. J. Phys. Chem. B 2014, 118, 10444-10459. [CrossRef] [PubMed]

28. Couling, D.J.; Bernot, R.J.; Docherty, K.M.; Dixon, J.K.; Maginn, E.J. Assessing the Factors Responsible for Ionic Liquid Toxicity to Aquatic Organisms via Quantitative Structure-Property Relationship Modeling. Green Chem. 2006, 8, 82-90. [CrossRef]

29. Pernak, J.; Sobaszkiewicz, K.; Mirska, I. Anti-Microbial Activities of Ionic Liquids. Green Chem. 2003, 5, 52-56. [CrossRef]

30. Saeman, J.F. Kinetics of Wood Saccharification-Hydrolysis of Cellulose and Decomposition of Sugars in Dilute Acid at High Temperature. Ind. Eng. Chem. 1945, 37, 43-52. [CrossRef]

31. Bhandari, N.; Macdonald, D.G.; Bakhshi, N.N. Kinetic Studies of Corn Stover Saccharification Using Sulphuric Acid. Biotechnol. Bioeng. 1984, 26, 320-327. [CrossRef] [PubMed]

32. O'Connor, R.T.; DuPré, E.F.; Mitcham, D. Applications of Infrared Absorption Spectroscopy to Investigations of Cotton and Modified Cottons: Part I: Physical and Crystalline Modifications and Oxidation. Text. Res. J. 1958, 28, 382-392. [CrossRef]

33. Suliter, A.; Hames, B.; Ruiz, R.; Scarlata, C.; Sluiter, J.; Templeton, D.; Crocker, D. Determination of Structural Carbohydrates and Lignin in Biomass; Technical Report; National Renewable Energy Laboratory: Golden, CO, USA, 2008.

(C) 2017 by the authors. Licensee MDPI, Basel, Switzerland. This article is an open access article distributed under the terms and conditions of the Creative Commons Attribution (CC BY) license (http:/ / creativecommons.org/licenses/by/4.0/). 